\title{
MODÈLE DE GESTION PRÉVISIONNELLE D'UN ATELIER DE PRODUCTION DE PORCELETS
}

\author{
P. MARTIN \\ Laboratoire de Recherches sur l'Économie des Industries alimentaires, \\ C. E. R. D. I. A., \\ 91 - Massy \\ Institut national de la Recherche agronomique \\ RÉSUMÉ
}

- Que produire?

- Quand produire? En quelles quantités?

- Doit-on faire une croissance continue et régulière ou une croissance par bandes?

- Doit-on fonder une politique de gestion d'un atelier de production sur le cycle des prix du porc? Etc.

Pour répondre à toutes ces questions, l'éleveur ne peut compter que sur son expérience antérieure et les informations plus ou moins dégradées qu'il reçoit de l'environnement. De plus, il ne peut vérifier le bien-fondé de la décision prise à un moment donné que lorsqu'il peut appréhender les effets de cette décision, c'est-à-dire lorsque cette dernière est consommée (même s'il s'est trompé). Il y a donc là une carence qu'il faut absolument pallier. Tenter d'y remédier revient à se demander :

- Peut-on prévoir tous les effets d'une décision?

- Peut-on avant même de réaliser effectivement un projet, quantifier toutes ses conséquences?

Cet exposé a pour objet de vous montrer, à l'aide de quelques illustrations (dont l'abondance dépendra de l'état d'avancement des travaux) qu'il est possible de répondre à ces questions.

\section{SUMMARY}

\section{FORECAST MANAGEMENT OF PIGLET ENTERPRISE}

- What is to be produced?

- When ? Which quantities?

- The growth shall it be steady and regular or by batches?

- The management policy of a piglet enterprise shall it be based upon the cycle of pig prices? Etc. 
To answer these questions, the farmer can only trust his own previous experience and the more or less complete informations from the environment. Moreover, he can only check the merits of the decision taken at a given moment when the effects of this decision are revealed, that means when the latter is consumed (even if he was wrong). The problem shown is very important. If we try to find a solution, the following questions may be asked :

- Is it possible to forecast all the effects of a decision?

- Is it possible, even before the very realization of a project, to quantify its consequences?

The aim of this is to show by means of some illustrations (the number of which will depend upon the state of advancement of the work) that it is possible to answer these questions.

\title{
MAITRISE DU CYCLE GESTRIEN DE LA TRUIE
}

\author{
F. DU MESNIL DU BUISSON et P. MAULÉON
}

\author{
Station de Physiologie de la Reproduction, \\ Contre de Recherches de Tours, \\ 37 - Nouzilly \\ Institut national de la Recherche agronomique
}

\section{RÉSUMÉ}

Deux techniques de maîtrise de l'œstrus ont été expérimentées sur 230 truies Large White : A, fluorogestone acetate par voie vaginale (éponge) avec ou sans PMSG ; B, méthallibure par voie orale et PMSG avec ou sans HCG.

Technique A, appliquée à des truies en fin de lactation.

Pour $70 \mathrm{p}$. Ioo des truies, l'œstrus induit débute entre le $2^{\mathrm{e}}$ et le $5^{\mathrm{e}}$ jour après la fin du traitement. Le taux de mise bas a été de 85,3 après double saillie et de 69,0 p. Ioo après double insémination (I. A.) avec détection d'oestrus sans verrat. Les pertes fréquentes d'éponge rendent cette technique difficilement utilisable dans la pratique.

Technique B, appliquée à des truies nullipares.

Le moment de l'ovulation par rapport au début des chaleurs a été déterminé par examen cœelioscopique. Chez les truies en cycle naturel, l'ovulation commence $38,47 \mathrm{~h} \pm 2$,or et finit $4^{2,27} \mathrm{~h} \pm 2,48$ après le début des chaleurs. Le moment de l'ovulation des truies traitées est relié à celui du début de l'œstrus plus qu'à celui des injections : après PMSG seul, l'ovulation est retardée de 3 heures en moyenne; l'injection de HCG l'avance de 5 heures, à condition qu'elle soit faite 